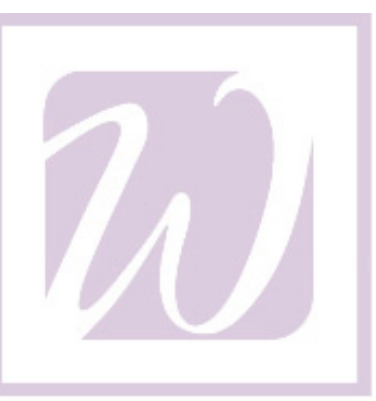

UW-WHITEWATER

State Rights over Water and Agricultural Productivity:

Evidence from the Krishna Basin

By

Shreyasee Das

Working Paper 12 - 03

University of Wisconsin - Whitewater

Department of Economics

$4^{\text {th }}$ Floor Hyland Hall

800 W. Main Street

Whitewater, WI 53190

Tel: (262) $472-1361$ 


\title{
State Rights over Water and Agricultural Productivity: \\ Evidence from the Krishna Basin
}

\author{
Shreyasee Das ${ }^{*}$ \\ University of Wisconsin-Whitewater
}

December, 2012

\begin{abstract}
This paper analyzes the effects of intrastate water reallocation on agricultural productivity. Specifically, I look at the 1976 Krishna Water Dispute Tribunal that reallocated the rights of three Indian states over the Krishna River. I exploit districttime variation in access to water to obtain causal effects of water reallocation on crop output and yield. I find that on average, the decision reduces district output by 7.7 percent and yield by 5.5 percent. The weak negative net effects of the decision are comprised of productivity gains for the most downstream state, Andhra Pradesh, that are more than offset by the productivity losses for the upstream states Maharashtra and Karnataka. The negative impacts for Maharashtra, which are especially pronounced during periods of drought, are significant at conventional significance levels. Thus, the 1976 reallocation of state rights over water from the Krishna Basin was redistributive and weakly reduced overall efficiency.
\end{abstract}

JEL Classifications: D23, O13, Q15

Keywords: Agricultural Productivity, Water, Property Rights Reallocation

\footnotetext{
Das: Assistant Professor, Department of Economics, University of Wisconsin-Whitewater, Email: dass@ uww.edu. I am grateful to Aimee Chin, Scott Imberman, Dietrich Vollrath, Adam Perdue, Teodora Stoica, Michael Clar and participants in the University of Houston graduate research workshop and 2011 STATA Conference for helpful comments. I would also like to thank Dr. Trent Biggs at San Diego State University for providing me with the discharge data for Vijayawada.
} 
"I have witnessed the conversion of my land from a water abundant country to a water stressed country." - Vandana Shiva, Water Wars: Privatization, Pollution and Profit

\section{Introduction}

River waters have long been the basis of conflict, both nationally and internationally. Usually the downstream parties demand more access to the river; their upstream counterparts tend to have more control over the river. Conflicts intensify when parties decide to build projects (canals, dams) on the rivers and/or their tributaries, thus blocking the water's natural flow (Iyer, 2007). In India, water wars have been waged for centuries. The Cauvery River dispute has been going on since 1892, conflict over the Indus River between India and Pakistan began when India was partitioned right after its Independence in 1947, and the Farakka Water treaty between India and Bangladesh with respect to the Ganges River was brought up in the 1970s. The dispute over the Krishna River among the three riparian states has ensued since the early 1900s, and despite many attempts to settle it, a binding agreement was not in place until 1976; this 1976 agreement is the subject of this paper.

Rivers are examples of common pool resources: goods that are non-excludable but rival in consumption. There are a number of international doctrines pertaining to decisions solving water disputes. Most prominent are the Helsinki Rules on the Uses of the Waters of International Rivers of 1966, and the United Nations Convention on the Law of NonNavigational Uses of International Watercourses of $1997 .{ }^{1}$ These redistribution rules abide by the concept of equitable appropriation which states that the river is to be viewed as common property and that the concerned parties will be allocated water on various factors that include the geography of the basin, the hydrology of the basin, climate, economic and

\footnotetext{
${ }^{1}$ Helsinki Rules on the Uses of the Waters of International Rivers of 1966 spell out the principle of equitable sharing for beneficial uses while the United Nations Convention on the Law of Non-Navigational Uses of International Watercourses of 1997 details the utilization of water in an equitable and reasonable manner
} 
social needs of the basin and population. India has its own set of doctrines to resolve disputes: the Interstate Water Disputes Act of 1956, which allows state governments to complain regarding river waters, and the National Water Policy of 1987 and 2002, which recognizes a river basin as the primary unit for water resources development and management.

Reallocating water among states involves redistribution, typically from upstream parties (who usually have better access to the water) to downstream parties. It is theoretically ambiguous whether on net, efficiency increases; this depends on whether the marginal productivity of water is higher upstream or downstream. Assessing which party has higher marginal productivity can be difficult, since the incentives to invest can change after reallocation. In agriculture, for example, a change in water rights might change investments in irrigation and cropping patterns, among other things. The literature with respect to water allocation and water management more generally is interdisciplinary and has been largely descriptive (Section 2.2 provides a discussion of the related literature). Though claims have been made about the depletion of water and the potential negative consequences for productivity, and case studies exist about productivity declines due to water reallocation ${ }^{2}$, there are no studies that rigorously evaluate the effect of reallocation of state rights over water on agricultural productivity. This paper attempts to fill this gap by analyzing the impact of one particular water reallocation in India on agricultural productivity: the allocation of the Krishna Basin waters decided by the Krishna Water Dispute Tribunal (KWDT) in 1976. The evaluation of this water reallocation is of interest for several reasons.

\footnotetext{
${ }^{2}$ In the matter of the Cauvery Water dispute, the downstream state of Tamil Nadu has always extensively used the river water for its irrigation, while Karnataka, the upstream state, started late with its irrigation and has extensively controlled the flow of water to the downstream areas. This has been associated with a productivity loss in the Thanjavore district in Tamil Nadu, which is one of the largest producers of paddy in the basin. However, it is difficult to attach a causal interpretation to this observed reduction in productivity, as there could be secular time changes in productivity unrelated to Karnataka's control of water upstream.
} 
The Krishna Basin is one of the largest river basins in India, located in three states that collectively make up one-fifth of India's total population. Understanding the effect of the 1976 Tribunal decision is therefore important to the region, and could help policymakers design policies that raise food supplies, raise efficiency, or reduce poverty. The experience in Krishna Basin could illuminate issues in reallocation of water rights that others in India and outside it could learn from as they contend with their own water disputes.

To identify the effect of the 1976 water reallocation on agricultural productivity, I take advantage of district-time variation in exposure to the decision. In particular, only after 1976 is the water reallocation in effect, and moreover, it is the districts located adjacent to the Krishna Basin whose access to water could be changed due to the water reallocation. This enables me to use a difference-in-differences strategy in which the change over time in agricultural productivity in the districts adjacent to the basin in excess of the change in districts located farther out is interpreted as the effect of the 1976 water reallocation. In the presence of differential trends in agricultural outcomes between the districts located closer and farther from the Krishna Basin, the difference-in-differences estimate would not give the effect of the water reallocation. Thus, in my preferred specification below, I control for district-specific time trends.

I apply this difference-in-differences strategy to a district panel data set covering all 63 districts of the three concerned states for the period of 1971-1999. My main finding is that the decision reduces agricultural productivity, though this is not significant at any conventional levels. I also look at the effect of the decision during drought periods, and find a negative (however not statistically significant) net effect on agricultural productivity; although the magnitude of the effect is higher than that of non-drought periods. When I allow 
heterogeneity in effect of the decision by state, I find that the decision increases productivity in the most downstream state, Andhra Pradesh, reduces productivity in the two upstream states, Maharashtra and Karnataka. The negative impacts for Maharashtra, which are especially pronounced during periods of drought, are significant at conventional significance levels. Taken together, these results indicate that the 1976 reallocation of state rights over water from the Krishna Basin was redistributive (with Andhra Pradesh gaining at the expense of its upstream neighbors) and weakly reduced overall efficiency.

The rest of the paper is organized as follows. Section 2 provides a background on the Krishna Water Dispute Tribunal, followed by a brief discussion of the related literature. Section 3 explains the theoretical framework for thinking about the impact of the water reallocation and elaborates on the empirical strategy. Section 4 describes the data. Section 5 presents the estimation results and I conclude in Section 6.

\section{Background}

\subsection{The Krishna Water Dispute Tribunal}

The Krishna River is the second largest river in Peninsular India. It rises from the Western Ghats near Mahabaleshwar and flows eastwards into the Bay of Bengal. The Krishna Basin spreads over 99,980 square miles $\left(258,000 \mathrm{~km}^{2}\right)$ across three states: Maharashtra (upper riparian), Karnataka (middle riparian) and Andhra Pradesh (lower riparian). ${ }^{3}$ The basin is further divided into 12 sub-basins. Figure 1 shows a map of the basin and the sub-basins. The Southwest Monsoon that spans from June to September/October is the main source of water in the basin. Canal irrigation is the primary method of irrigation,

\footnotetext{
${ }^{3}$ Before the reorganization of states in 1956, the riparian provinces were Bombay, Madras, Hyderabad and Mysore.
} 
followed by tanks and wells. The soil in the region is primarily black soil and alluvial soil. The main crops of the basin are jowar, bajra, cotton, paddy and sugarcane.

The Krishna Basin has witnessed conflict between upstream and downstream parties for centuries. Most of the dispute has focused on which state has primary rights over the water, and also on various projects that were built on the river, thus curbing the natural flow of the river. There were contracts written between the states in 1933, 1944 and 1951, but arguments ensued about the validity of these agreements. Prior to the formation of the Krishna Water Dispute Tribunal in 1969, "the States were reduced simply to 'parties to the disputes', comparable to individual landowners quarrelling over withdrawals from watercourses that run through their properties" (D'Souza, 2006). Thus contracts regarding water sharing were difficult to enforce, with parties unhappy with the contract continuing to fight for a better allocation instead of abiding by it. To contest the 1951 agreement regarding the allocation of the Krishna waters, which Karnataka believed overly favored the downstream state Andhra Pradesh; Karnataka moved the central government to adjudicate the matters of the Krishna waters. The case was filed with the Indian Supreme Court in 1962 and a decision stipulating a new water allocation became effective in 1976.

After Karnataka filed the case in 1962, the Krishna Water Dispute Tribunal was set up in 1969 in accordance with Section 2(c) and Section 3 of the Interstate Water Dispute Act of $1956 .{ }^{4}$ The Tribunal consisted of one former Indian Supreme Court judge, and two former judges from the highest court of two states not party to the dispute. The Tribunal sought advice and testimony from the concerned parties as well as technical experts. Karnataka was the main complainant and Andhra Pradesh the main opponent in the dispute. Maharashtra

\footnotetext{
${ }^{4}$ Section 2(c) lays down the foundation that a "water dispute" implies that it is a dispute or difference between two or more state governments with respect to the use, distribution of the water of an inter-state river. Section 3 enables a state government to make a complaint regarding water disputes.
} 
joined Karnataka as a complainant in this case. The primary point of dispute between the parties was to determine if the 1951 agreement remained valid. The upstream parties (Karnataka and Maharashtra) contended that the 1951 agreement was struck among entities that no longer existed due to the 1956 reorganization of states, and was based on many projects that had either been abandoned or modified, and thus was no longer valid. The downstream party (Andhra Pradesh) argued that the 1951 agreement was still valid.

The Krishna Water Dispute Tribunal announced its decision in 1973. The Tribunal concluded that the 1951 agreement was not valid and that the three states were not bound by that agreement. The Tribunal then stipulated a new water allocation: out of an estimated 2060 thousand million cubic feet (TMC) of total dependable flow ${ }^{5}$ provided by the Krishna Basin, Maharashtra was allocated 565 TMC; Karnataka 695 TMC; and Andhra Pradesh 800 TMC. The decision was finalized in 1976 and henceforth became binding on the three states. ${ }^{6}$ The intent of the Tribunal was to increase equity amongst the three states involved in the dispute, while maintaining as well as possible individual state's efficient use of water in agricultural productivity.

\footnotetext{
${ }^{5}$ Dependable flow is "the magnitude of river flow which may be assuredly expected at a given point on the river on some scientific or rational basis inspiring confidence" (Krishna Water Dispute Tribunal, 1973a, page 74). There are two approaches to calculate dependable flow; runoff and stream flow. Runoff is rainfall that is not absorbed by the soil finding its way into the river channel. River discharge (also sometimes called stream flow) is the volume rate of water flow (the residual amount available in a drainage basin). Stream flow was the preferred method of estimation since it also represents the integrated results of all meteorological and hydrological factors operative in the drainage basin and is the only phase of the cycle for which reasonably accurate measurements can be made of the volumes involved (Bruce and Clark, 1976). Discharge was calculated at the Bezawada (Vijayawada) site in Andhra Pradesh and the percentage dependability of the Krishna River at Vijayawada was calculated to be $75 \%$, which works out to 2060 TMC.

${ }^{6}$ In addition to the above allocation (also known as Scheme A of the KWDT), Scheme B of the KWDT determined the distribution of the surplus water in the basin. The surplus was determined to be $330 \mathrm{TMC}$, and was to be divided thus, 25\% to Maharashtra, 50\% to Karnataka and 25\% to Andhra Pradesh. However, the implementation of this Scheme required the constitution of the Krishna River Valley Authority, which was never realized. Thus, Andhra Pradesh was given access to use any surplus waters, but could not claim rights to it.
} 
To regulate the implementation of the allocations, the Tribunal listed out a monitoring scheme. At all dams and weir sites (existing, under construction, and future projects) that utilize more than 1 TMC annually, discharge measurements were to be made three times a day. ${ }^{7}$ In addition, the Central Water Commission (CWC) set up gauge sites on state rivers and interstate rivers and streams; these were to be monitored three times daily as well. All monitoring costs were to be borne by state governments. Water management techniques in the basin include dams, reservoirs, canals, and tube-wells.

Before turning to estimate the effect of the 1976 Tribunal decision reallocating states' rights over water in the Krishna Basin on agricultural productivity, it is useful to assess how the decision impacted water flows downstream. Data on discharge along the Krishna Basin prior to the 1976 decision are not widely available; in fact, as mentioned above, it was not until after the decision that attention was paid to the collection of such data. For one station in Andhra Pradesh though-Vijayawada - I have managed to obtain monthly discharge data for 1965-2000 (Biggs et al., 2007 and 2008). ${ }^{8}$ It is an important station since it was the site primarily used to make the rulings of the allocation, and moreover, it is where the river forms the Krishna Delta and flows into the sea. Figure 2 shows the location of the station.

To examine the effect of the Tribunal's decision on the flow of water, I perform a simple before-after analysis (unfortunately, given the data available, it is not possible to separate the true effect of the decision on water flow from changes in water flow that would have occurred over time irrespective of the decision). Figure 3, Panel A shows the mean discharge (averaged over 12 months of each calendar year) by year and Panel B shows the variance of the 12 months of discharge by year. Visually, it appears that the mean level and

\footnotetext{
${ }^{7}$ The daily three times are 6 A.M., 12 Noon, and 6 P.M.

${ }^{8} \mathrm{I}$ am grateful to Dr. Trent Biggs for sharing these data with me.
} 
variance of discharge have decreased in the post-1976 period. This is corroborated by the regression analysis of Table 1. All specifications include rainfall as a control variable since rainfall is an important source of water in the basin. In Column 1, monthly discharge is the dependent variable, and I find that on average discharge significantly decreases after the Tribunal decision. In Column 2, I look at average monthly discharge over each calendar year and still find a significant decline in discharge in the post-water reallocation period.

Columns 3 and 4 relate to within-year fluctuations in discharge rather than the level of discharge. Column 3 shows that discharge significantly decreases in all months except the summer months. ${ }^{9}$ The discharge significantly increases in the summer months after the decision (the point estimate is $1.189=-7.492+8.681$ and is significant at the $5 \%$ level of confidence). This suggests that during the drier part of the year, there is more water flow than what would be expected if the decline in level of discharge in Columns 1 and 2 applied uniformly across months. This is in line with the research by Biggs et al. $(2007,2008)$ and Venot et al. (2007). The KWDT had defined a typical water year as June $1^{\text {st }}$ to May $31^{\text {st }}$ each year. One potential explanation of the increase in discharge during the summer months could be that the upstream states were trying to meet the allocations towards the end of the water year, which coincidentally falls during the summer months. However, it is also consistent with upstream states releasing more water when the downstream is drier for other reasons, such as increased pressure to release water when supply is naturally low downstream. Column 4 explicitly shows that the variance of discharge declines in Vijayawada after the Tribunal decision.

While the results of Table 1 do not say anything about what happened in the upstream states, they do suggest a decrease in the level and variance flow to Vijayawada. Hydrology

\footnotetext{
${ }^{9}$ Summer in India is typically between the months of March and May.
} 
research suggests that the Krishna Basin is facing water shortage (hence the lower flows perhaps), however during times of higher demand for water (in the analysis, the summer months) it appears that more water is being released from upstream, leading to more stable water flows throughout the year.

\subsection{Related Literature}

A large literature has focused on the provision of common pool resources and public goods. There are broadly two things that these papers focus on: the need for cooperation among parties who are beneficiaries to the resources and the control aspect of it. Ostrom (2003) finds that some ownership rights towards common pool resources can result in effective governing and managing of systems. ${ }^{10}$ Boucher and Branoillé (2010) provide evidence of cooperation at the country level. They argue that contributors to a public good increase participation but lower parties' efforts when there is uncertainty.

The other set of literature has highlighted provision of public goods based on who controls these goods. Banerjee and Somanathan (2006) discuss how public goods are allocated by a centralized state and note that politically disadvantaged groups have also been able to extract public resources from the state; however, it is not the same across all minority groups. Besley and Coate (2003) suggest that sharing costs in a centralized system clouds efficient policy making since it does not keep local needs into account. ${ }^{11}$ A handful of other studies examine the relationship between property rights allocation and economic efficiency. Besley and Ghatak (2010) theorize that for a non-binding resource constraint, improving property rights of an insecure asset involved in the production process (e.g. land) can improve economic efficiency. Banerjee, Gertler and Ghatak (2002) find evidence of an

\footnotetext{
${ }^{10}$ Also see Ostrom and Gardner (1993), Ostrom, Gardner and Walker (1994), Steins and Edwards (1999).

${ }^{11}$ See Bardhan and Mookherjee (2006), Besley et al. (2003) and Besley et al. (2004) for more on this topic.
} 
increase in agricultural productivity when tenants have more secure land rights. Bardhan (2000) finds that usually, rich farmers violate water allocation rules within an irrigation community. He also points out that obedience might not be an indicator of cooperation among farmers since they might be better off without the rules.

Also related to my study is research in the area of hydrology that has been done on the Krishna Basin. ${ }^{12}$ One focus of this research has been about the closing of the river, i.e., it can no longer sustain any large irrigation projects since its efficiency has reached a maximum. In addition to the research presented by Venot (2008), Biggs et al. (2007) and Venot et al. (2007) find that the stream flow in the Krishna Basin has dramatically decreased, with the effects aggravated during drought years. Gaur et al. (2008) estimate cropping pattern and water supply changes during the drought of 2000-2003 and formulate methods to sustain such shocks. However, these papers have largely focused on the Lower Krishna Basin and the Krishna Delta (two lower sub-basins of the Krishna Basin) and usually use a short panel dataset.

Adding to the problem of overuse is the issue of low quality irrigation techniques in the basin. Wallach (1984) points out that in the Krishna Basin, although cultivated land grew over $80 \%$ (post-independence in 1947 to the 1970s), water had not reached most parts due to leaky canals. Shah (2005) finds that groundwater irrigation is being heavily exhausted because of lack of good canals, tube wells and irrigation and hence allocation schemes are by and large wasted because of faulty irrigation methods. A handful of studies have also focused on the efficiency of dam constructions on rivers. Duflo and Pande (2007) find that dams increase agricultural productivity and reduce vulnerability against rainfall shocks in the

\footnotetext{
${ }^{12}$ D'Souza (2006) provides a detailed description of the history on the Krishna Water Dispute and a thorough insight into the Tribunal's decision.
} 
districts downstream from where dams are built. On the other hand, Gamage and Smakhtin (2009) suggest that large-scale expansion of dams and barrages over the rivers have reduced flow into the sea. They focus on the Krishna Basin and note that upstream reservoir storage developments are to blame for this.

The main contribution of my paper is that I quantify the effects of redistribution of state rights over water within an entire basin, over an extended period of time. In particular, I look at the impact of the 1976 Krishna Water Dispute Tribunal decision that shifted state rights over water from the Krishna Basin. My research tries to link the literature on the use of water in agricultural production and the research on property rights (in my case water rights). To my knowledge, it is the first study on the effects of court-ordered water distributions on agricultural outcomes.

\section{Empirical Strategy}

\subsection{Conceptual Framework}

A simple model where states are treated as profit-maximizing firms can provide a useful framework for understanding what could be the impact of a redistribution of state rights over water. ${ }^{13}$ Consider two states (upstream and downstream) that share a river basin. Suppose the total amount of water in the river is $\bar{w}$. Each state maximizes profit with respect to water

$$
\max _{w} \pi=f(w) * p-c(w)
$$

where $\pi$ is the profit, $f(w)$ is a concave production function $\left(f^{\prime}(w)>0, f^{\prime \prime}(w)<0\right), p$ is output price and $c(w)$ is the cost function and is non-decreasing in water. For simplicity let us

\footnotetext{
${ }^{13}$ State governments and their politicians may well have other objectives, but profit maximization nevertheless provides a useful reference point.
} 
assume that the cost of production is just the net cost of controlling the water. To maximize profits, each state will produce output where marginal revenue equals marginal cost, i.e., $f^{\prime}(w) * p=c^{\prime}(w)$. Upstream has first access to water, and so it will use water until the marginal profit from using the additional unit of water is zero; let $w^{u}$ denote the profitmaximizing amount of water for the upstream state. Assuming the downstream state had the same technology, costs, and price, then downstream would also like to choose $w^{u}$ to maximize its profits. However, there will not be enough water to permit downstream to also choose $w^{u}$, when $2 w^{u}>\bar{w}$; in this case the resource constraint is binding and the best downstream can do is to choose $w^{d}<w^{u}$ where $w^{u}+w^{d}=\bar{w}$.

Without any allocation rules, each state maximizes its own profits, and $f^{\prime}\left(w^{u}\right)<$ $f^{\prime}\left(w^{d}\right)$, i.e., the marginal product of an additional unit of water is less in the upstream state than in the downstream state. This is inefficient, as reallocating a unit of water from upstream to downstream would increase output and profit. Indeed, if the two states were to jointly make production decisions (e.g., a social planner acting on behalf of the two states, trying to maximize total profit), then water would have been allocated such that the last unit of water provides the same extra profit in the two states. Generally, this means that the new profitmaximizing amount of water used by the upstream state decreases from $w^{u}$ to $w^{u 2}$. and that used by the downstream state increases from $w^{d}$ to $w^{d^{2}}$. In the case where the states are identical in technology, costs and price, and where the resource constraint binds, then each state should use $\frac{\bar{w}}{2}$.

Let $y$ denote the total output in the region. Without any allocation rules, each state maximizes its own profit, and the total output is:

$$
y_{\text {alone }}=f\left(w^{u}\right)+f\left(w^{d}\right)
$$


If states behaved jointly, total output would be:

$$
y_{\text {joint }}=f\left(\frac{\bar{w}}{2}\right)+f\left(\frac{\bar{w}}{2}\right)
$$

and given the concavity of the production function it can be seen that $y_{\text {joint }}>y_{\text {alone }}$. Thus, for the region as a whole, there is an increase in output.

Figure 4 illustrates the above arguments in graphical form. Panel A shows the effects on the upstream state, and Panel B shows the effects on the downstream state. I use a linear marginal benefit curve for simplicity (the results are similar for a non-linear marginal benefit curve). At point A, the upstream maximizes its total profit where marginal benefit is zero, given the current amount of water it uses, $w^{u}$. Point B is where downstream produces given $w^{d}$ amount of water. If they were to jointly make the output decision, i.e., where marginal benefits are equalized, they would produce at point $\mathrm{C}$, with upstream using $w^{u^{2}}$ and downstream using $w^{d^{2}}$. Thus, the upstream state decreases output moving from stand-alone to joint profit maximization, the downstream state increases output, and output increases overall.

To summarize, in the case where the resource constraint is binding, a reallocation of water from an area of lower marginal productivity of water to an area of higher marginal productivity of water is predicted to raise overall output and yield (with the higher marginal productivity area gaining in output and the lower marginal productivity one losing in output). However, it is theoretically possible that water reallocation might lead to lower output. This would happen if water were reallocated from a higher marginal productivity area to a lower marginal productivity area. While this is not something a profit maximizing decision-maker would intentionally do, this could arise for sensible reasons. For example, the equitable appropriations guideline for solving water disputes stipulates that decision-makers consider 
equity as an important goal, and decision-makers who weigh equity heavily in their social welfare function more may well redistribute water in favor of the lower marginal productivity party. Also, allocation decisions are being made under imperfect information about each state's marginal productivities, hence even decision-makers who care only about efficiency could ex post have reallocated to lower productivity areas.

Additionally, in theory, the effect of the water reallocation could have zero impact on output. This is consistent with several scenarios. First, the resource constraint may not be binding - the water that the upstream state left for downstream use may exceed the optimal amount demanded by the downstream state. In my empirical analysis below, I allow the effect of the allocation to vary between drought and non-drought periods in the region; the rationale is that the resource constraint is more likely to be binding during a drought period than a non-drought period. Second, the allocations may not be enforced, in which again nothing changes from the pre-decision situation of each state maximizing its own profit. Also, if there were already some private bargaining in place prior to the 1976 water reallocation, then this reallocation would not achieve any efficiency increase and the net effect of the allocation would be zero.

Given the foregoing discussion, it is theoretically ambiguous what the effect of the reallocation of states' rights over the Krishna Basin is on agricultural productivity. Next, I describe my methodology for identifying the causal effect of water reallocation.

\subsection{Identification Strategy}

The decision of the Krishna Water Dispute Tribunal redistributes rights over water from the Krishna River among the three states bordering it. There are two sources of variation in exposure to this water reallocation. On the one hand, there is time variation: the 
decision is effective beginning in 1976. On the other hand, there is cross-sectional variation, with the water reallocation affecting the water access of districts located closer to the Krishna River. Using the time variation alone would not permit identification of the causal effect of the water allocation because agricultural outcomes would have differed before and after 1976 even without the reallocation. As well, using the cross-district variation alone would not permit identification of the causal effect because the districts adjacent to the Krishna River are different from the farther away districts in ways that affect the outcomes (e.g., water availability, soil type, topography). Therefore, I exploit both sources using a difference-indifferences identification strategy.

Specifically, I estimate the effect of water reallocation by taking the after-before difference in outcomes for the districts located inside the Krishna Basin (i.e., adjacent to the basin; below, I refer to these as "inside" districts), and subtracting out the after-before difference in outcomes for districts located outside the basin to remove the secular time effect. This strategy is summarized by the following equation:

$$
y_{d t}=\alpha+\beta\left(\text { inside }_{d} * \text { post }_{t}\right)+\rho\left(\text { rainfall }_{d t}\right)+\delta_{d}+\theta_{t}+\varepsilon_{d t}
$$

where $y_{d t}$ is a measure of agricultural productivity of district $d$ in time $t$, post $t_{t}$ is a dummy variable for observations in years 1976 or later, inside $_{d}$ is a dummy variable for the districts located inside the Krishna Basin, rainfall $d_{t}$ is the rainfall shock, $\delta_{d}$ is district fixed effects, $\theta_{t}$ is year fixed effects, and $\varepsilon_{d t}$ is the error term. The coefficient of primary interest is $\beta_{1}$, which is the difference-in-differences estimate. ${ }^{14}$ In order to interpret this coefficient as the effect of the 1976 decision reallocating states' rights over the Krishna Basin, the parallel trend

\footnotetext{
${ }^{14}$ Compared to the raw difference-in-differences estimate, which is (mean $y$ for inside districts after 1976 minus mean $y$ for inside districts before 1976)- (mean y for outside districts after 1976 minus mean y for outside districts before 1976), this one controls for main effects more fully (time dummies are more detailed than controlling just for a "post" dummy, and district dummies are more detailed than controlling for just an "inside" dummy) and for rainfall.
} 
assumption must hold: in the absence of the water reallocation policy, the change over time in productivity in the inside districts would have been the same as the change over time in productivity in the outside districts.

The district panel data I use for my empirical analysis has several years of pre-1976 data to permit explicitly controlling for differential trends. One method I use is to control for a time trend that is specific to the inside districts:

$$
y_{d t}=\alpha+\beta\left(\text { inside }_{d} * \text { post }_{t}\right)+\rho\left(\text { rainfall }_{d t}\right)+\delta_{d}+\theta_{t}+\lambda\left(\text { inside }_{d} * \text { year }_{t}\right)+\varepsilon_{d t} .
$$

A second method controls for district-specific time trends, which is a more exhaustive control for differential trends than what is encapsulated by Equation 2:

$$
y_{d t}=\alpha+\beta\left(\text { inside }_{d} * \text { post }_{t}\right)+\rho\left(\text { rainfall }_{d t}\right)+\delta_{d}+\theta_{t}+\lambda_{d}\left(\text { year }_{t}\right)+\varepsilon_{d t} .
$$

The difference-in-differences estimates in Equations 2 and 3 provide the effect of the water reallocation even if there is a differential trend between districts closer to and farther from the Krishna Basin, so long as the differential trend that would have applied in the post1976 period mirrors the recent historical trend. Gradual expansion of irrigation, or gradual adoption of new agricultural technologies like high yield variety seeds, are two important forces underlying trends in agricultural productivity in Maharashtra, Karnataka and Andhra Pradesh over this time period, hence these inside-specific and district-specific time trends credibly capture much of the differential time effects between inside and outside districts.

If the water allocations stipulated by the 1976 decision are not binding, then we do not expect the decision to have any impact. For example, there may be enough water for everyone, and so productivity does not change. During droughts, there is likely to be excess demand for water, and the allocations are more likely to be binding. Therefore, I modify the previous models to incorporate heterogeneity in effect by drought and non-drought periods. 
A district-year is classified as under drought if the rainfall shock in that year falls below the $20^{\text {th }}$ percentile of rainfall shock in the three states. When a district's own rainfall is below expectation, then demand for water from other sources (such as the Krishna Basin) is especially high. It is an empirical question whether the water reallocation on the whole mitigates or amplifies the harmful effects of drought on agricultural productivity. For downstream districts, the harmful effects could be mitigated because the water reallocation assures a steady release of water from upstream (subject to the annual and monthly flows stipulated in the decision). However, for upstream districts, the very same steady releases of water could amplify the harmful effects of drought because at their highest time of need for non-rain sources of water, they may need to release some water to abide by the decision. To assess whether the water reallocation on net changes the effect of droughts on agricultural productivity, I estimate the following equation:

$$
\begin{array}{r}
y_{d t}=\alpha+\beta_{1}\left(\text { inside }_{d} * \text { post }_{t}\right)+\beta_{2}\left(\text { inside }_{d} * \text { post }_{t} * \text { drought }_{d t}\right)+\gamma_{1}\left(\text { post }_{t} * \text { drought }_{d t}\right) \\
+\gamma_{2}\left(\text { inside }_{d} * \text { drought }_{d t}\right)+\gamma_{3}\left(\text { drought }_{d t}\right)+\beta_{3}\left(\text { rainfall }_{d t}\right)+\delta_{d}+\theta_{t}+\varepsilon_{d t}
\end{array}
$$

where drought $_{d t}$ is a dummy variable for district $d$ having a drought at time $t$. $\beta_{1}$ gives the effect of the water reallocation on agricultural productivity during non-drought periods, and $\beta_{2}$ gives the differential effect during drought periods. A positive $\beta_{2}$ would suggest that on net, the water reallocation mitigates the harm of droughts, while a negative $\beta_{2}$ would suggest that on net, the water reallocation amplifies the harm of droughts (which would be an unintended consequence.

The analysis has thus far focused on estimating net effects of the water redistribution across the three states involved in the decision. This is of primary interest because this answers the question of whether the policy raised efficiency. However, given that the decision basically redistributes water from upstream state Maharashtra to downstream states 
Karnataka and Andhra Pradesh, it is also of interest to assess which states gain and which lose (if any). Therefore I modify Equations 1 to 4 to allow for state-specific effects of the water reallocation.

\section{Data}

I implement my identification strategy using a district panel data set that is used by Duflo and Pande (2007). ${ }^{15}$ The dataset is an extension of the Evenson and McKinsey India Agriculture and Climate dataset (Evenson and McKinsey, 1999). ${ }^{16}$ The dataset contains variables related to agricultural production collected from various Indian government publications as well as rainfall ${ }^{17}$ for 271 Indian districts in 13 Indian states from 1956-2004. I restrict this data to the three states in the Krishna Basin, namely Maharashtra, Karnataka and Andhra Pradesh. There are 63 districts in total, with 24 districts falling within the Krishna basin ("inside" districts) and 39 outside. My main analysis uses data for 1971-1999; this restriction is made for practical reasons the rainfall variable is available only for these years; but still provides a good number of before and after years of data.

The two main measures of agricultural productivity that I use are total production and total yield. Total production, measured in rupees per thousand tons, is the value of the production of the main crops (at average crop prices in 1960-65). Total yield, measured as Rupees per hectare, is total production divided by cultivated area. The main crops consist of water-intensive crops (rice, sugarcane, cotton and wheat) and non-water intensive crops (bajra, jowar and pulses).

\footnotetext{
${ }^{15}$ Data downloaded from Institute for Quantitative Social Science at Harvard University, http://dvn.iq.harvard.edu/dvn).

${ }^{16}$ These data are available for download from the BREAD website, http://ipl.econ.duke.edu/dthomas/dev_data/index.html.

${ }^{17}$ Rainfall in this dataset is the district's fractional deviation from its mean over the 1971-1999 period.
} 
Table 2 provides descriptive statistics of the district panel data that I use for my main empirical analysis. Figures 5 and 6 show mean output and yield, respectively, by state and year in inside and outside districts. The average log of total production is 9.67 Rupees per thousand tons and average log of total yield is 4.12 Rupees per hectare. While output is higher in inside districts at the outset of the water reallocation, yield is similar between inside and outside districts.

\section{Estimation Results}

\subsection{Effect of Water Redistribution on Agricultural Productivity}

I first estimate the overall net effect of water reallocation on total production and total yield. These results are presented in Table 3. The difference-in-differences estimate of the effect of water reallocation is given by the coefficient for the "Post*Inside" interaction term.

Column 1 reports the results of estimating Equation 1 with log total production as the dependent variable using ordinary least squares. I obtain a difference-in-differences estimate of 0.035 . This coefficient is not statistically significantly different from zero at conventional confidence levels. In order to interpret this coefficient as the effect of water reallocation, the parallel trend assumption must hold: in the counterfactual where the decision did not happen, the change in output over time would have been the same in the inside districts (located adjacent to the Krishna Basin) and the outside districts (located further away). In Column 2, I add a control for a time trend specific to inside districts (i.e., Equation 2) and obtain an adjusted difference-in-differences estimate of $-0.077 .{ }^{18}$ In Column 3, I add district-specific time trends (i.e., Equation 3), and obtain an adjusted difference-in-differences estimate of -

\footnotetext{
${ }^{18}$ It is interesting that the coefficient decreases after adjusting for a differential trend between inside and outside districts - this suggests that in the absence of the decision, output would have grown faster in the inside region.
} 
0.076 , though neither of these estimates is significant at conventional levels of significance. ${ }^{19}$ Thus there is weak evidence that the decision reduced output. The point estimate in Column 3 indicates that the 1976 reallocation reduced annual district output by an average of 7.6 percent. The $95 \%$ confidence interval is $[-0.186,0.034]$, which means that I can rule out output gains greater than 0.034 and output losses less than -0.186 at the $5 \%$ significance level. In the right panel of Table 3, I conduct a similar analysis with log of total yield as the dependent variable. The difference-in-differences estimate is -0.008 in Column 4 . The difference-in-differences estimate is -0.055 when I control for inside-specific and districtspecific linear trends (Columns 5 and 6), indicating that the 1976 reallocation reduced annual district yield by an average of 5.5 percent. The $95 \%$ confidence interval is $[-0.131,0.021]$, which means that the yield losses will not be less than -0.131 and yield gains are limited to 0.021 .

The main finding from Table 3 is that the water reallocation weakly reduced agricultural output and yield on net within the three states involved in the Tribunal's decision. In Table 4, I explore whether the net effect of water reallocation differs during drought and non-drought periods. The first row shows the coefficient for the "Post*Inside" interaction, and reflects the net effect of water reallocation during non-drought periods. The second row shows the difference in effect between drought and non-drought periods (thus, the effect of water reallocation during drought periods is the sum of these two coefficients; this figure is displayed in the bottom row of the table). Column 1 (Column 4) shows the results of estimating Equation 4 with log total production (log total yield) as the dependent

\footnotetext{
${ }^{19}$ Also, the standard errors I use are rather conservative, robust not only to arbitrary heteroscedasticity but also arbitrary serial correlation within districts.
} 
variable, Column 2 (Column 5) adds a time trend specific to inside districts, and Column 3 (Column 6) adds district-specific time trends.

I find that during non-drought periods, the net effect of water reallocation is negative, though not significantly different from zero (Table 4, first row). During drought periods, the net effect becomes more negative (second row gives the difference in effect, bottom row reports the total net effect during drought periods), though neither the effect during drought periods nor the difference in effect between drought and non-drought periods is significant. These results are suggestive of the decision amplifying the harmful effects of drought, however, due to the imprecision of the estimates we cannot rule out that the effect of water reallocation is no different between drought and non-drought periods.

Did the redistribution lead to some winners and losers in terms of agricultural productivity, or did it have a uniform effect on all three states? I re-estimate the preceding models allowing the effects of water reallocation to vary by state. Table 5 presents these results. The odd columns use basic difference-in-differences estimation (as in Equation 1), and the even columns control for district-specific trends (as in Equation 3). The results in Table 5 indicate that the decision was redistributive-it reduced output and yield in Maharashtra and Karnataka, and increased output and yield in Andhra Pradesh. The decision reduces output by $14.8 \log$ points and yield by $14.0 \log$ points in Maharashtra (Columns 2 and 6, first row), and these estimates are significant at the 10 percent level of significance. Much of the negative impact of the decision in Maharashtra comes during drought periods. The bottom of Column 8 indicates that for Maharashtra during drought periods, the water allocation reduced total yield by $24 \log$ points and production decreased by $20 \log$ points (bottom of column 4); both the results are significant at the 5\% level. These results of lower 
productivity especially during drought periods due to the decision is consistent with Maharashtra having to release water downstream at a steady pace, regardless of its own water needs. The gain in output that Andhra Pradesh experiences can be attributed to the discharge results presented in Table 1 - there is a decrease in variance of water flow, and water flow during summer months was higher than expected after the 1976 decision.

Although the estimated effects are not in general significant for Karnataka and Andhra Pradesh, the pattern of results in Table 5 suggest a redistribution of water in favor of the downstream state, with the cost borne by upstream neighbors. Such a redistribution may well have been intended by the Tribunal, who were trying to adhere to the equitable appropriations doctrine. However, it is not clear whether reducing overall efficiency and amplifying the harm of droughts for Maharashtra in the magnitudes shown in my tables were the cost the Tribunal was willing to pay for the increased equity-perhaps some of these effects were unintended consequences.

\subsection{Robustness Checks}

\subsubsection{Severity of Drought}

My analyses thus far have shown that the decision hurts agricultural productivity during drought periods (at least weakly; the estimates are imprecise, so often they are not significant at the conventional levels). However, a potential confounding factor is the severity of droughts in the drought periods. The drought dummy variable I use takes on the value one for $20 \%$ of the sample by construction; hence one could argue that the intensity of the drought could vary, and if by chance the post-1976 has a larger share of severe droughts in the inside districts, this could cause large negative estimated effects in output and yield for 
reasons having nothing to do with the decision. To check if this is indeed the case, I make the following adjustments to my estimations. First, I add a control for severity of drought (an interaction between the drought variable and the rainfall deviation variable) to Equation 3. This allows for rainfall shock to have a different effect during drought and non-drought periods. Columns 1, 2, 5 and 6 of Table 7 report these results. A second way I account for the drought severity is by dropping the worst drought seasons, which I construct as the bottom $5 \%$ of the rainfall shock. This precludes the possibility of a few devastating droughts driving the results. Columns 3, 4, 7 and 8 present these results. The estimation results controlling for severity of the drought in these two ways are basically the same as the original results in Table 3 and 4, suggesting that differential severity of droughts is not biasing my estimates of the effect of the water reallocation. Table 7 reports results for the state-wise estimations, and the results are similar to Table 5.

\subsubsection{Other Robustness Checks}

Duflo and Pande (2007) show that dams increase agricultural productivity and reduce susceptibility to rainfall shocks in districts that are downstream from where the dams are built. To the extent that dam construction is correlated with the interaction term "Post*Inside", then the coefficient for this variable would not be interpretable as the effect of the water reallocation, as it could also be capturing effects of dam construction. To address this concern, I control for number of dams using the variable from Duflo and Pande (2007) and my results are basically unchanged. ${ }^{20}$

An additional concern is that with a long post-decision time window (my analysis extends from 1971-1999, so the post-decision period is 24 years), there could be other

\footnotetext{
${ }^{20}$ The district-time data on the number of completed dams by Duflo and Pande (2007) is derived from the World Registry of Large Dams.
} 
policies, not just the construction of dams, that are correlated with the "Post*Inside" dummy. Therefore, I narrow the time window around the decision and find qualitatively similar results.

\section{Conclusion}

This paper estimates the effect of redistributing water rights among states on agricultural productivity. The 1976 decision of the Krishna Water Dispute Tribunal provides district-time variation in access to water from the Krishna River. I exploit this variation using a difference-in-differences strategy to identify the effect of water reallocation on agricultural productivity. I find that, on net, there is weak evidence that the water reallocation lowers agricultural productivity. I also find that the decision significantly lowered output and yield in Maharashtra, especially during drought periods. Additionally, the decision lowers productivity in Karnataka and raises it in Andhra Pradesh. These state-wise effects taken together clearly indicate that a redistribution away from the two upstream states toward the downstream state.

Various international and Indian doctrines governing the resolution of water disputes have often pushed for "equitable appropriation", i.e., increasing equity amongst parties without compromising much on individual riparian's efficient use of water. My results are consistent with following this principle: equity is improved (downstream party benefits), though there is an efficiency cost. The point estimates suggest a $7.7 \%$ decline in output and $5.5 \%$ decline in yield (these effect sizes are not economically significant). It is impossible to know whether the entirety of these net productivity losses were part of the tradeoff that the Tribunal intentionally made to gain more equity, or whether at least some of the losses were 
unintended consequences. However, unintended or not, efficiency losses are associated with the 1976 agreement, and it is worth considering whether there are more efficient ways to improve equity than water reallocation. Evaluating the KWDT's decision is important because the Krishna Basin is a water source for many people and is an important region for agricultural production. However, the external validity of these estimates may be limited. Each basin is different with respect to its inherent characteristics, but more importantly they are different with respect to the nature of the dispute, so what is found for the Krishna Basin may not necessarily apply elsewhere. Moreover, my analysis is restricted to a particular allocation- that stipulated by the 1976 Tribunal decision. It is likely that some other allocation for the same basin would have had different consequences. ${ }^{21}$

My work is the first to highlight the effects of a water reallocation decision on agricultural productivity. My results indicate the vagueness of the 1976 decision and the need to make future allocations more precise. In particular, that the upstream state Maharashtra and middle riparian Karnataka are worse off, while the downstream state of Andhra Pradesh is better off, especially during drought periods, suggest that there might be need for flexible allocations; state-contingent allocations might be better than having rigid allocations. This will allow for some flexibility when a state is experiencing an extreme rainfall shock, to achieve their goals.

\footnotetext{
${ }^{21}$ A new decision regarding the Krishna Waters was reached in 2010; it will be interesting to evaluate the new allocation and see how the effects compare to what is estimated here.
} 


\section{References}

Banerjee, Abhijit, Paul J. Gertler and Maitreesh Ghatak. "Empowerment and Efficiency: Tenancy Reform in West Bengal,” Journal of Political Economy, 110(2): 239-280, 2002.

Banerjee, Abhijit and Rohini Somanathan. "The Political Economy of Public Goods: Some Evidence from India," Journal of Development Economics, 82(2): 287-314, 2007.

Bardhan, Pranab. "Irrigation and Cooperation: An Empirical Analysis of 48 Irrigation Communities in South India," Economic Development and Cultural Change, 48(4): 847$865,2000$.

Bardhan, Pranab and Dilip Mookherjee. "Decentralization \& Accountability in Infrastructure Delivery in Developing Countries," The Economic Journal, 116(508): 101- 127, 2006.

Becu, N., P. Perez, A. Walker, O. Barreteau, and C. Le Page. "Agent Based Simulation of a Small Catchment Water Management in Northern Thailand: Description of the CATCHSCAPE Model," Economic Modelling, 170: 319-331, 2003.

Besley, Timothy and Stephen Coate. "Centralized vs. Decentralized Provision of Local Public Goods: A Political Economy Approach," Journal of Public Economics, 87(12)2611-2637, 2003.

Besley, Timothy and Maitreesh Ghatak. "Property Rights and Economic Development," Handbook of Development Economics, Volume 5, Rodrik, D. and M. Rosenzweig, eds,. Amsterdam: North-Holland, 2010.

Besley, Timothy, Rohini Pande and Vijayendra Rao."Just Rewards? Local Politics \& Public Resource Allocation in South India." World Bank Economic Review, Forthcoming.

Besley, Timothy, Rohini Pande, Lupin Rahman, and Vijayendra Rao. "The Political Economy of Public Good Provision: Evidence from Indian Local Governments," Journal of European Economic Association Papers and Proceedings, 2(2-3): 416-426, 2004.

Biggs, Trent W, Christopher A. Scott, Anju Gaur, Jean-Phillippe Venot, Thomas Chase, and Eungul Lee. "Impacts of Irrigation and Anthropogenic Aerosols on the Water Balance, Heat Fluxes, and Surface Temperature in a River Basin," Water Resources Research, 44: 2008.

Biggs, Trent W., Anju Gaur, Christopher A. Scott, Prasad Thenkabail, Parthasaradhi Gangadhar Rao, Mural Krishna Gumma, Sreedhar Acharya and Hugh Turral. "Closing of the Krishna Basin: Irrigation development, Streamflow Depletion, and Macroscale Hydrology," IWMI Research Report 111, International Water Management Institute, Colombo, Sri Lanka, 2007.

Boucher, Vincent and Yann Branoillé. "Providing Global Public Goods under Uncertainty," Journal of Public Economics, 94: 591-603, 2010. 
Bruce, James P. and Robert H. Clark. Introduction to Hydrometeorology, Pergamon Press, 1966.

Central Water Commission (India). Integrated Hydrological Hand Book, various years.

Ciriacy-Wantrup, S.V. "Some Economic Issues in Water Rights" Journal of Farm Economics, 37(5): 875-885, 1955.

Davidson, Brian, Petra Hellegers and Madar Samad. "Assessing the Economic Impact of Redistributing Water within a Catchment: A Case Study of the Musi Catchment in the Krishna Basin” IMWI Working Paper 134, 2009.

Dinar, Ariel, Stefano Farolfi, Fioravante Patrone and Kate Rowntree. "To Negotiate or to Game Theorize: Evaluating Water Allocation Mechanisms in the Kat Basin, South Africa," Game Theory and Policymaking in Natural Resources and the Environment, 85$111,2008$.

D’Souza, Radha. Interstate Disputes over Krishna Waters: Law, Science and Imperialism. Orient Longman Private Limited, 2006.

Duflo, Esther, and Rohini Pande. "Dams," Quarterly Journal of Economics, 122(2):601-646, 2007.

Evenson, Robert E., and James McKinsey. "Technology Climate Interactions in the Green Revolution," Economic Growth Center, Yale, 1999.

Gamage, Nilantha and Vladimir Smakhtin. "Do River Deltas in East India Retreat? A Case of the Krishna Delta," Geomorphology, 103: 533-530, 2009.

Gaur, Anju, Trent W. Biggs, M.K. Gumma, G. Parthasaradhi and H. Turral. "Water Scarcity Effects on Equitable Water Distribution and Land Use in a Major Irrigation Project Case Study in India," Journal of Irrigation and Drainage Engineering 134(1): 26-35, 2008.

George, Biju, Hector M Malano and Brian Davidson. "Integrated Water AllocationEconomic Modelling at a Catchment Scale," MODSIM-2007, Christchurch, Dec 10-14, 2007.

Inocencio, Arlene \& McCornick, Peter G. "Economic Performance of Public Investments in Irrigation in India in the Last Three Decades," Conference Papers h041802, International Water Management Institute., 2008.

Irrigation \& CAD Department, Government of Andhra Pradesh. Krishna Water Dispute Tribunal Award, http://www.irrigation.ap.gov.in/kwdtaward.html .

Iyer, Ramaswamy. Towards Water Wisdom: Limits, Justice, Harmony, Sage Publications India Pvt. Ltd., 2007. 
Iyer, Ramaswamy. WATER: Perspectives, Issues, Concerns, Sage Publications, 2003.

Khagram, Sanjeev. Dams and Development: Transnational Struggles for Water and Power. Cornell University Press. 2004.

Kumar, Dinesh M. "Impact of Electricity Prices and Volumetric Water Allocation on Energy and Groundwater Demand Management: Analysis from Western India," Energy Policy, 33: 39-51, 2005.

Mays, Larry W. Water Resources Handbook, McGraw Hill, 1996.

Ministry of Water Resources, India. Inter- State River Water Disputes Act 1956. http://wrmin.nic.in/.

Ostrom, Elinor. "How Types of Goods and Property Rights Jointly Affect Collective Action," Journal of Theoretical Politics, 15(3): 239-270, 2003.

Ostrom, Elinor and Roy Gardner. "Coping with Asymmetries in the Commons: Self Governing Irrigation Systems can Work," The Journal of Economic Perspectives, 7(4): 93-112, 1993.

Ostrom, Elinor, Roy Garnder and James Walker. Rules Games and Common Pool Resources. The University of Michigan Press. 1994.

Rao, K.L. India's Water Wealth: Its Assessment, Uses and Projections, Sangam Books Limited, 1996.

Reidinger, Richard B. "Institutional Rationing of Canal Water in Northern India: Conflict between Traditional Patterns and Modern Needs," Economic Development and Cultural Change, 23(1): 79-104, 1974.

Richards, Alan and Nirvikar Singh. "Inter State Water Disputes in India: Institutions and Policies", Development and Comp Systems, EconWPA, 2004.

Rooijen, Daniel J. Van, Hugh Turral and Trent W. Biggs. "Urban and Industrial Water Use in the Krishna Basin, India", Irrigation and Drainage, 2008.

Salman, Salman M. A. "The Helsinki Rules, the UN Watercourses Convention and the Berlin Rules: Perspectives on International Water Law," Water Resources Development, 23(4): 625-640, 2007.

Sangal, S.P. "Pricing of Irrigation Waters in India," Economic and Political Weekly, 26(46): 2645-2651, 1991.

Sekhri, Sheetal. "Public Provision \& Protection of National Resources: Groundwater Irrigation in Rural India," American Economic Journal: Applied Economics 29-55. 2011. 
Shah, Tushaar, Mark Giordan and Jinxia Wang. "Irrigation Institutions in a Dynamic Economy: What Is China Doing Differently from India?" Economic and Political Weekly, 39(31): 3452-3461, 2004.

Shiva, Vandana. Water Wars: Privatization, Pollution, and Profit, India Research Press, 2002.

Steins, Nathalie A. and Victoria M. Edwards. "Platforms for Collective Action in MultipleUse Common Pool-Resources," Agriculture and Human Values, 16: 241-255, 1999.

Venot, Jean-Phillipe, Luna Bharati, Mark Giordano and François Mollé. "Beyond Water, Beyond Boundaries: Spaces of Water Management in the Krishna River Basin, South India," The Geographic Journal, 177(2): 160-170, 2011.

Venot, Jean Phillippe. "Drawing Water for Thirsty Lands: Stories of the Closing Krishna Basin in South India," 13 $3^{\text {th }}$ World Water Congress, September 2008.

Venot, Jean Phillipe, Hugh Turral, Madar Samad, and François Mollé. "Shifting Waterscapes: Explaining Basin Closure in the Lower Krishna Basin, South India," Research Report 121, International Water Management Institute, 2007.

Wade, Robert. "Village Republics: Economic Conditions for Collective Action in South India," Orient Longman Limited, 1989.

Wallach, Bret. "Irrigation Developments in the Krishna Basin since 1947," Geographical Review, 70(2): 127-144, 1984.

White, Anderson T. and C. Ford Runge. "Common Property and Collective Action: Lessons from Cooperative Watershed Management in Haiti," Economic Development and Cultural Change, 43(1): 1-41, 1994. 
Figure 1: Map of Krishna Basin

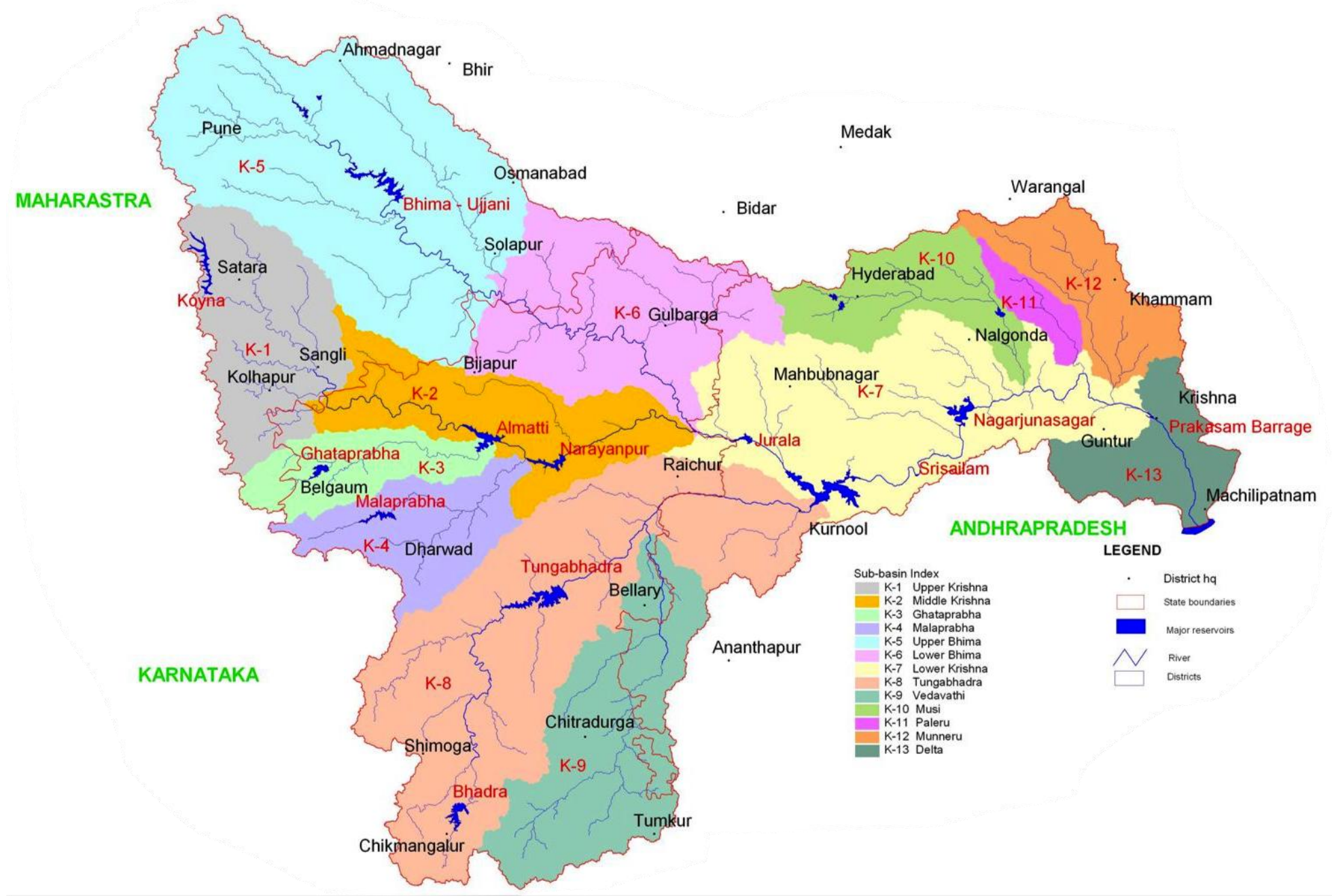

Source: International Water Management Institute 
Figure 2: Vijayawada Station in the Krishna Basin

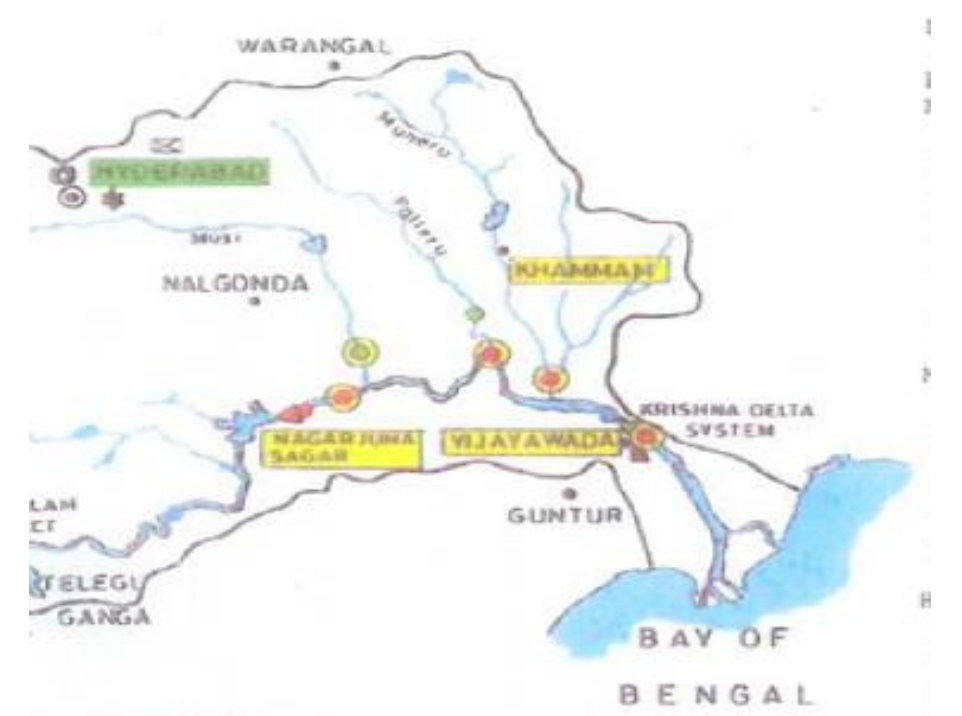

Source: Integrated Hydrological Data Book, Central Water Commission, 2009 
Figure 3: Discharge at Vijayawada

Panel A

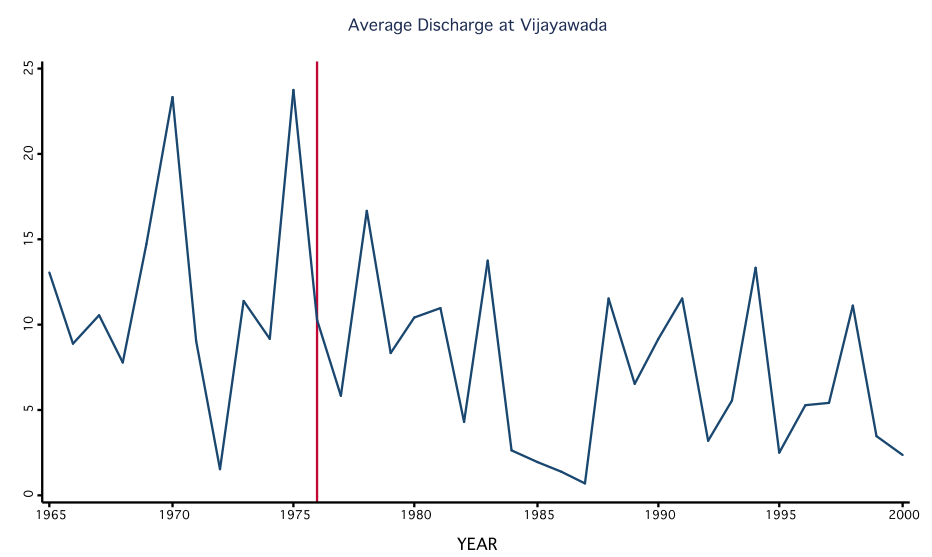

Panel B

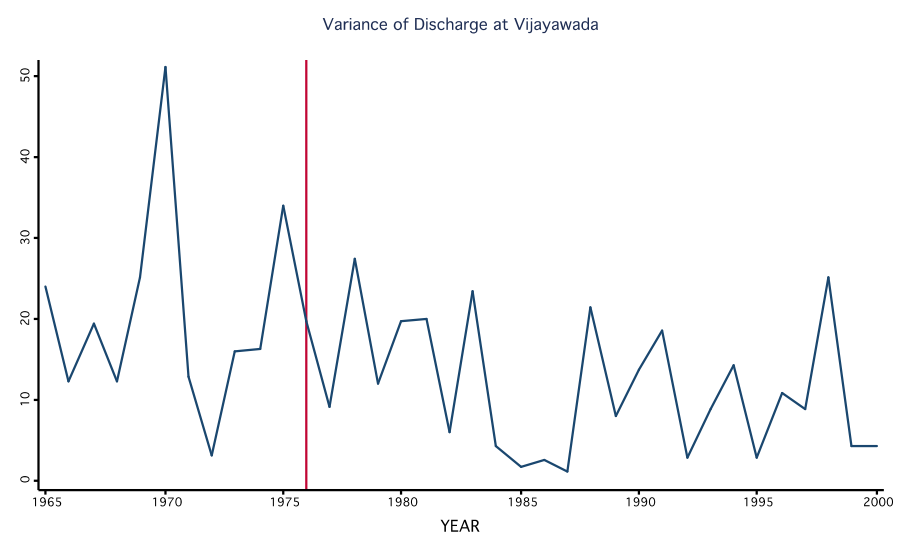

33 
Figure 4: Effect of Redistribution of Water on Marginal Benefit of Upstream and Downstream States

Panel A: Upstream State

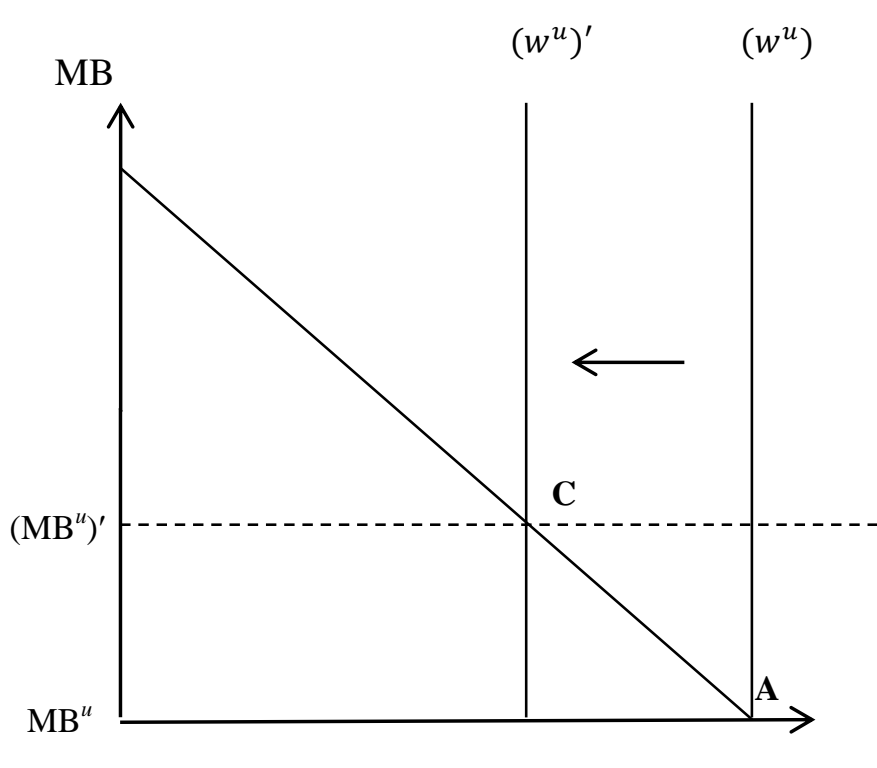

Panel B: Downstream State

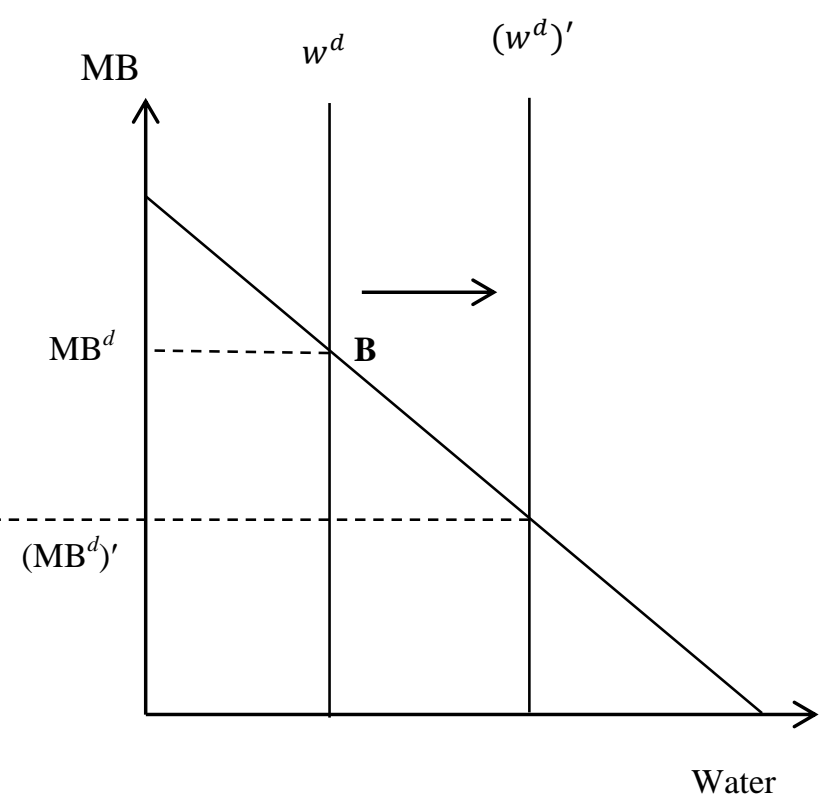


Figure 5: Mean Log of Total Production by State, Year and Inside/Outside Districts

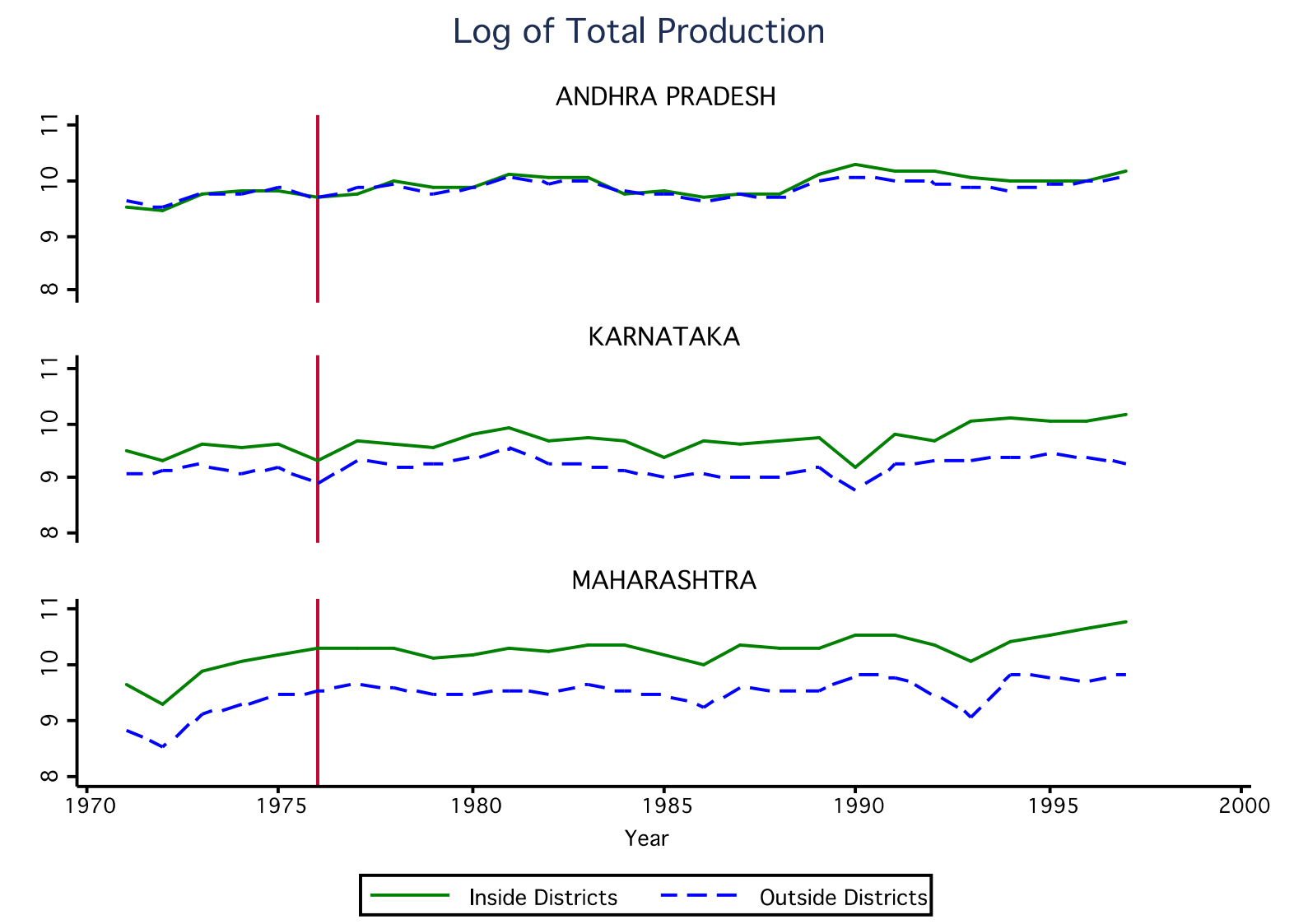




\section{Figure 6: Mean Log of Total Yield by State, Year and Inside/Outside Districts}

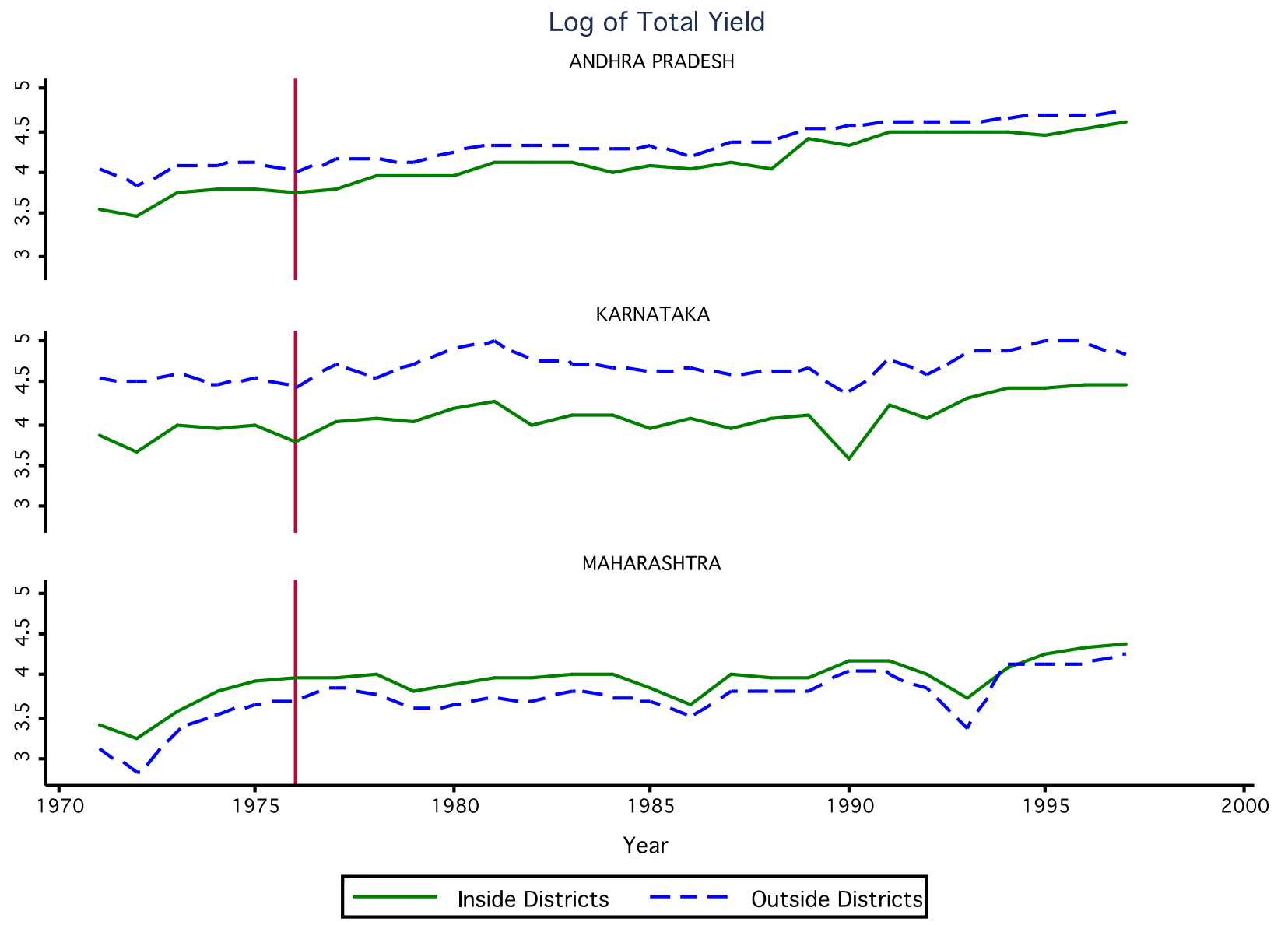


Table 1: Discharge at Vijayawada After the Decision

\begin{tabular}{|c|c|c|c|c|}
\hline & $\begin{array}{l}\text { Monthly } \\
\text { Discharge }\end{array}$ & $\begin{array}{l}\text { Average } \\
\text { Discharge }\end{array}$ & $\begin{array}{l}\text { Monthly } \\
\text { Discharge }\end{array}$ & $\begin{array}{l}\text { Variance of } \\
\text { discharge }\end{array}$ \\
\hline & (1) & (2) & (3) & (4) \\
\hline Post & $\begin{array}{c}-5.321 * * * \\
(1.870)\end{array}$ & $\begin{array}{c}-6.636^{* * *} \\
(1.264)\end{array}$ & $\begin{array}{c}-7.492 * * * \\
(2.472)\end{array}$ & $\begin{array}{c}-9.789 * * * \\
(3.122)\end{array}$ \\
\hline Post*Summer & & & $\begin{array}{c}8.681 * * * \\
(2.517)\end{array}$ & \\
\hline Summer & $\begin{array}{c}-2.545^{* * *} \\
(0.704)\end{array}$ & & $\begin{array}{c}-8.309 * * * \\
(1.763)\end{array}$ & \\
\hline Monthly Rainfall & $\begin{array}{c}0.0819 * * * \\
(0.013)\end{array}$ & & $\begin{array}{c}0.0821 * * * \\
(0.013)\end{array}$ & \\
\hline Average Rainfall & & $\begin{array}{c}0.366^{* * *} \\
(0.046)\end{array}$ & & \\
\hline Variance of Rainfall & & & & $\begin{array}{c}0.387 * * * \\
(0.053)\end{array}$ \\
\hline Number of Observations & 432 & 36 & 432 & 36 \\
\hline $\mathrm{R}^{2}$ & 0.240 & 0.640 & 0.250 & 0.500 \\
\hline $\begin{array}{l}\text { Mean of dependent variable } \\
\text { (S.D.) }\end{array}$ & $\begin{array}{c}8.678 \\
(17.963)\end{array}$ & $\begin{array}{r}8.680 \\
(5.619) \\
\end{array}$ & & $\begin{array}{c}14.469 \\
(10.556)\end{array}$ \\
\hline
\end{tabular}

Notes: Robust standard errors in parentheses. $* * *, * *, *$ denotes significance at $1 \%, 5 \%$ and $10 \%$ respectively.

Discharge is measured as $\mathrm{mm} / \mathrm{month}$ and rainfall is measured in $\mathrm{mm}$. 
Table 2: Descriptive Statistics

\begin{tabular}{|c|c|c|c|c|c|c|c|c|c|c|}
\hline & & & \multicolumn{4}{|c|}{ Inside } & \multicolumn{4}{|c|}{ Outside } \\
\hline & \multicolumn{2}{|c|}{ Full Sample } & \multicolumn{2}{|c|}{ Before } & \multicolumn{2}{|c|}{ After } & \multicolumn{2}{|c|}{ Before } & \multicolumn{2}{|c|}{ After } \\
\hline & & Obs & & Obs & & Obs & & Obs & & Obs \\
\hline & (1) & (2) & (3) & (4) & $(5)$ & (6) & (7) & (8) & (9) & $(10)$ \\
\hline Log of Total Production & $\begin{array}{c}9.670 \\
(0.691)\end{array}$ & 1827 & $\begin{array}{c}9.658 \\
(0.573)\end{array}$ & 144 & $\begin{array}{c}9.981 \\
(0.712)\end{array}$ & 552 & $\begin{array}{c}9.288 \\
(0.579)\end{array}$ & 234 & $\begin{array}{c}9.573 \\
(0.644)\end{array}$ & 897 \\
\hline Log of Total Yield & $\begin{array}{c}4.120 \\
(0.643)\end{array}$ & 1827 & $\begin{array}{c}3.750 \\
(0.629)\end{array}$ & 144 & $\begin{array}{c}4.159 \\
(0.605)\end{array}$ & 552 & $\begin{array}{c}3.835 \\
(0.696)\end{array}$ & 234 & $\begin{array}{c}4.250 \\
(0.606)\end{array}$ & 897 \\
\hline Rainfall Deviation & $\begin{array}{l}<0.001 \\
(0.256)\end{array}$ & 1827 & $\begin{array}{l}-0.094 \\
(0.280)\end{array}$ & 144 & $\begin{array}{c}0.025 \\
(0.305)\end{array}$ & 552 & $\begin{array}{l}-0.081 \\
(0.218)\end{array}$ & 234 & $\begin{array}{c}0.021 \\
(0.218)\end{array}$ & 897 \\
\hline Drought & $\begin{array}{c}0.200 \\
(0.400)\end{array}$ & 1827 & $\begin{array}{c}0.319 \\
(0.468)\end{array}$ & 144 & $\begin{array}{c}0.219 \\
(0.414)\end{array}$ & 552 & $\begin{array}{l}0.278 \\
(.449)\end{array}$ & 234 & $\begin{array}{c}0.149 \\
(0.357)\end{array}$ & 897 \\
\hline
\end{tabular}

Notes: Observations are at the district-year level for all districts located in Maharashtra, Karnataka and Andhra Pradesh. Inside districts (24) are those located adjacent to the Krishna Basin, and outside districts (39) are the remaining districts. Production is measured in Rupees per thousand tons using average crop prices of 1960-1965. Yield is measured in Rupees per hectare. Rainfall deviation is the fractional deviation of rainfall from the mean at the district level (over 1971-1999). Drought is a dummy indicating that the observation is in the bottom quintile of rainfall deviation. 
Table 3: Difference-in-Differences Estimates of the Effect of Water Reallocation on Agricultural Productivity

\begin{tabular}{|c|c|c|c|c|c|c|}
\hline & \multicolumn{3}{|c|}{ Log of Total Production } & \multicolumn{3}{|c|}{ Log of Total Yield } \\
\hline & (1) & $(2)$ & (3) & (4) & (5) & (6) \\
\hline \multirow[t]{2}{*}{ Post*Inside } & 0.035 & -0.077 & -0.076 & -0.008 & -0.055 & -0.055 \\
\hline & $(0.065)$ & $(0.056)$ & $(0.056)$ & $(0.048)$ & $(0.039)$ & $(0.039)$ \\
\hline \multirow[t]{2}{*}{ Inside*Drought } & $0.127 * * *$ & $0.133 * * *$ & $0.130 * * *$ & 0.039 & 0.042 & 0.030 \\
\hline & $(0.047)$ & $(0.046)$ & $(0.035)$ & $(0.034)$ & $(0.034)$ & $(0.029)$ \\
\hline \multirow[t]{2}{*}{ Post*Drought } & $0.205^{* * *}$ & $0.205^{* * *}$ & $0.194 * * *$ & $0.117 * *$ & $0.118 * *$ & $0.109 * * *$ \\
\hline & $(0.058)$ & $(0.057)$ & $(0.043)$ & $(0.046)$ & $(0.046)$ & $(0.039)$ \\
\hline \multirow[t]{2}{*}{ Drought } & $-0.213^{* * *}$ & $-0.219 * * *$ & $-0.201 * * *$ & $-0.131 * * *$ & $-0.134 * * *$ & $-0.114 * * *$ \\
\hline & $(0.053)$ & $(0.053)$ & $(0.035)$ & $(0.041)$ & $(0.041)$ & $(0.036)$ \\
\hline \multirow[t]{2}{*}{ Rainfall Deviation } & $0.135^{*}$ & $0.122 *$ & $0.134 * * *$ & 0.024 & 0.019 & 0.046 \\
\hline & $(0.069)$ & $(0.065)$ & $(0.044)$ & $(0.047)$ & $(0.047)$ & $(0.041)$ \\
\hline Number of Observations & 1,827 & 1,827 & 1,827 & 1,827 & 1,827 & 1,827 \\
\hline $\mathrm{R}^{2}$ & 0.770 & 0.771 & 0.817 & 0.865 & 0.866 & 0.891 \\
\hline
\end{tabular}


Table 4: Effect of Water Reallocation by Drought/Non-Drought Periods

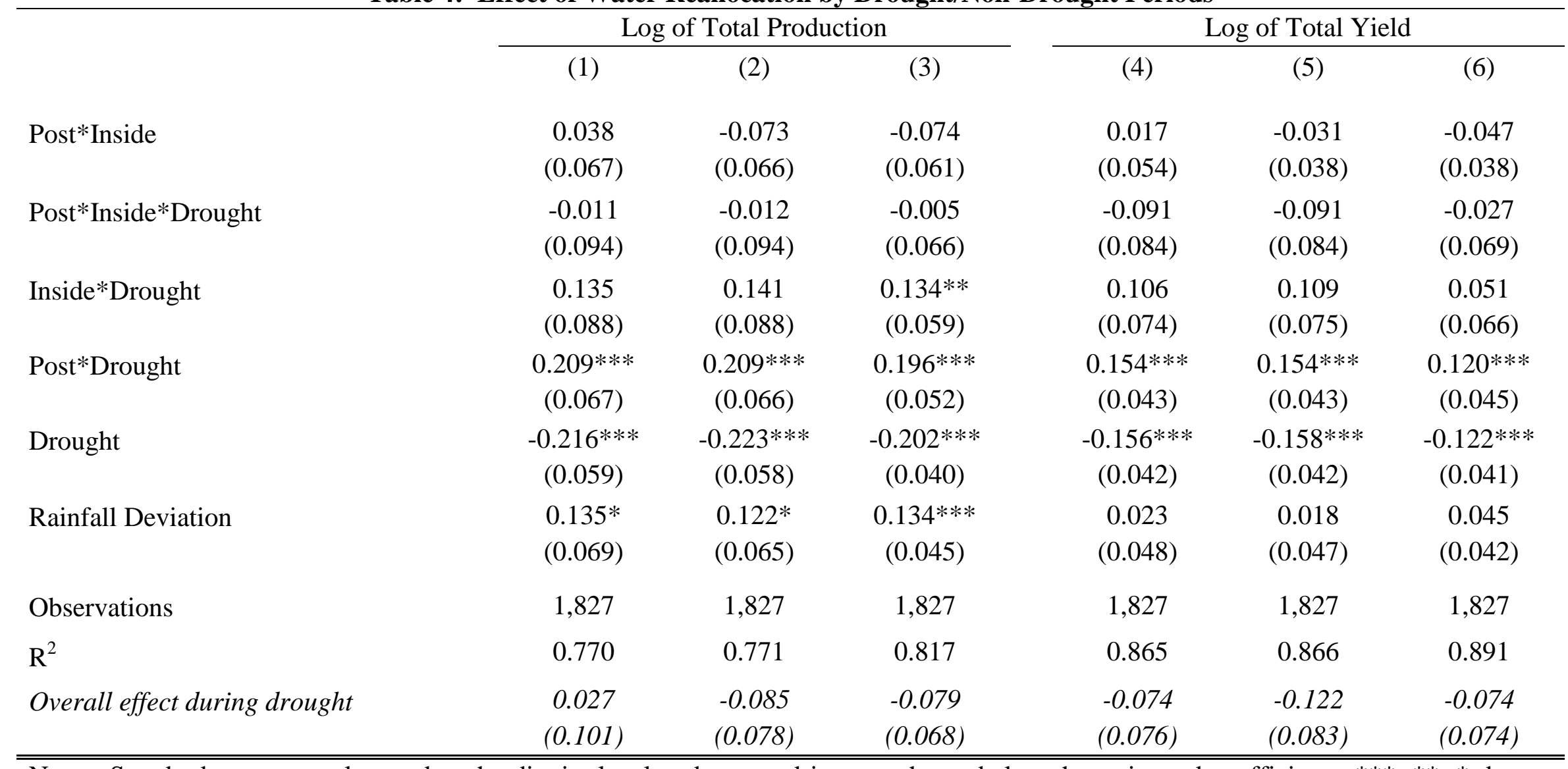

Notes: Standard errors are clustered at the district level and reported in parentheses below the estimated coefficient. ***, **,* denote significance at 1\%,5\% and 10\% respectively. All regressions include year and district fixed effects. . Columns (2) and (5) control for linear time trends specific to inside districts. Columns (3) and (6) control for district - specific time trends. The first row of coefficients gives the effect of water reallocation during non-drought periods, and the second row gives the difference in effect between drought and non-drought periods; the sum of these two coefficients gives the total effect during drought periods, and is reported in the bottom row. 
Table 5: Effect of Water Reallocation by State

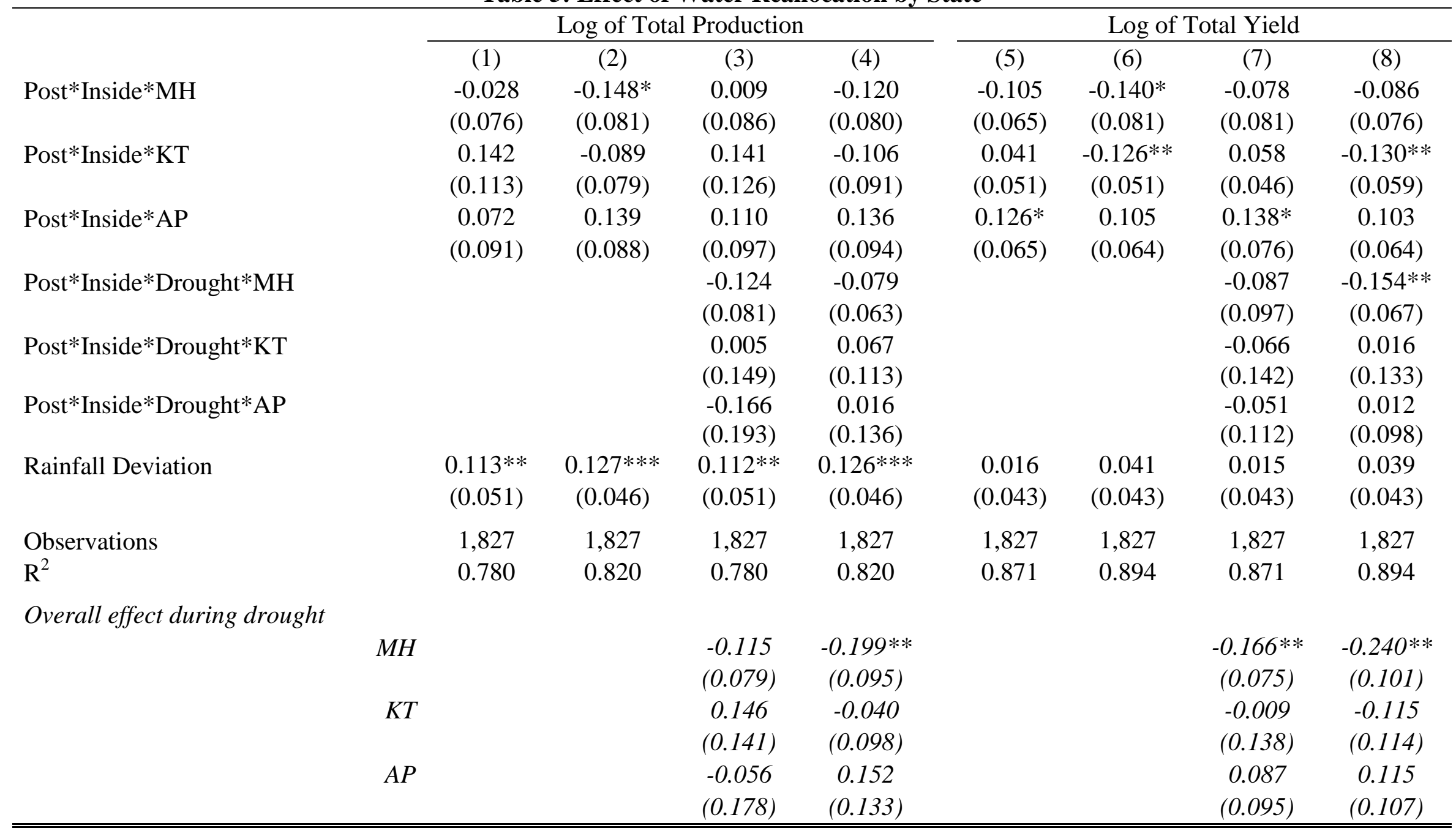

\footnotetext{
Notes: Standard errors are clustered at the district level and reported in parentheses below the estimated coefficient. $* * *, * *, *$ denote significance at 1\%,5\% and 10\% respectively. AP represents Andhra Pradesh, MH represents Maharashtra, KT represents Karnataka. All regressions also control for year and district fixed effects, inside*drought, post*drought and drought. Even columns also control for district-specific time trends.
} 
Table 6: Robustness Check -Controlling for Severity of Droughts

\begin{tabular}{|c|c|c|c|c|c|c|c|c|}
\hline & \multicolumn{4}{|c|}{ Log of Total Production } & \multicolumn{4}{|c|}{ Log of Total Yield } \\
\hline & (1) & (2) & (3) & (4) & (5) & (6) & (7) & (8) \\
\hline Post*Inside & $\begin{array}{l}-0.075 \\
(0.056)\end{array}$ & $\begin{array}{l}-0.077 \\
(0.060)\end{array}$ & $\begin{array}{l}-0.078 \\
(0.059)\end{array}$ & $\begin{array}{l}-0.069 \\
(0.060)\end{array}$ & $\begin{array}{c}-0.054 \\
(0.039)\end{array}$ & $\begin{array}{l}-0.049 \\
(0.037)\end{array}$ & $\begin{array}{l}-0.059 \\
(0.037)\end{array}$ & $\begin{array}{c}-0.053 \\
(0.038)\end{array}$ \\
\hline Post*Inside*Drought & & $\begin{array}{c}0.006 \\
(0.064)\end{array}$ & & $\begin{array}{c}-0.055 \\
(0.079)\end{array}$ & & $\begin{array}{c}-0.015 \\
(0.070)\end{array}$ & & $\begin{array}{c}-0.035 \\
(0.075)\end{array}$ \\
\hline Inside*Drought & $\begin{array}{c}0.146 * * * \\
(0.034)\end{array}$ & $\begin{array}{c}0.141 * * \\
(0.057)\end{array}$ & $\begin{array}{c}0.104 * * * \\
(0.036)\end{array}$ & $\begin{array}{c}0.148 * * \\
(0.061)\end{array}$ & $\begin{array}{c}0.047 \\
(0.029)\end{array}$ & $\begin{array}{c}0.058 \\
(0.064)\end{array}$ & $\begin{array}{c}0.012 \\
(0.027)\end{array}$ & $\begin{array}{c}0.039 \\
(0.065)\end{array}$ \\
\hline Post*Drought & $\begin{array}{c}0.182 * * * \\
(0.043)\end{array}$ & $\begin{array}{c}0.180 * * * \\
(0.052)\end{array}$ & $\begin{array}{c}0.110 * * \\
(0.045)\end{array}$ & $\begin{array}{c}0.127 * * \\
(0.056)\end{array}$ & $\begin{array}{c}0.096 * * \\
(0.040)\end{array}$ & $\begin{array}{c}0.102 * * \\
(0.044)\end{array}$ & $\begin{array}{c}0.054 \\
(0.040)\end{array}$ & $\begin{array}{c}0.065 \\
(0.052)\end{array}$ \\
\hline Drought*Rainfall Deviation & $\begin{array}{c}0.375^{*} \\
(0.214)\end{array}$ & $\begin{array}{l}0.376 * \\
(0.212)\end{array}$ & & & $\begin{array}{c}0.428 * * \\
(0.186)\end{array}$ & $\begin{array}{c}0.426^{* *} \\
(0.186)\end{array}$ & & \\
\hline Drought & $\begin{array}{l}-0.094 \\
(0.069)\end{array}$ & $\begin{array}{l}-0.093 \\
(0.070)\end{array}$ & $\begin{array}{c}-0.123^{* * *} * \\
(0.041)\end{array}$ & $\begin{array}{c}-0.136^{* * * *} \\
(0.048)\end{array}$ & $\begin{array}{c}0.007 \\
(0.063)\end{array}$ & $\begin{array}{c}0.002 \\
(0.066)\end{array}$ & $\begin{array}{l}-0.059 \\
(0.040)\end{array}$ & $\begin{array}{l}-0.067 \\
(0.049)\end{array}$ \\
\hline Rainfall Deviation & $\begin{array}{c}0.095 * \\
(0.053)\end{array}$ & $\begin{array}{l}0.095 * \\
(0.053)\end{array}$ & $\begin{array}{c}0.105 * * \\
(0.052)\end{array}$ & $\begin{array}{l}0.105^{*} \\
(0.053)\end{array}$ & $\begin{array}{l}0.0009 \\
(0.047)\end{array}$ & $\begin{array}{l}0.0007 \\
(0.048)\end{array}$ & $\begin{array}{c}0.019 \\
(0.048)\end{array}$ & $\begin{array}{c}0.019 \\
(0.049)\end{array}$ \\
\hline Observations & 1,827 & 1,827 & 1,735 & 1,735 & 1,827 & 1,827 & 1,735 & 1,735 \\
\hline $\mathrm{R}^{2}$ & 0.817 & 0.817 & 0.816 & 0.816 & 0.892 & 0.892 & 0.889 & 0.889 \\
\hline Overall effect during drought & & $\begin{array}{l}-0.071 \\
(0.068)\end{array}$ & & $\begin{array}{l}-0.123 \\
(0.090)\end{array}$ & & $\begin{array}{l}-0.064 \\
(0.074)\end{array}$ & & $\begin{array}{l}-0.088 \\
(0.076)\end{array}$ \\
\hline
\end{tabular}

Notes: Standard errors are clustered at the district level and reported in parentheses below the estimated coefficient. $* * *, * *, *$ denote significance at $1 \%, 5 \%$ and $10 \%$ respectively. Columns (3), (4), (7) and (8) drop the drought observations falling in the lowest 5 percent of rainfall deviation. All regressions also control for year and district fixed effects, and district-specific time trends. 
Table 7: Robustness Check - State-wise Estimates Controlling for Severity of Droughts

\begin{tabular}{|c|c|c|c|c|c|c|c|c|c|}
\hline & & \multicolumn{4}{|c|}{ Log of Total Production } & \multicolumn{4}{|c|}{ Log of Total Yield } \\
\hline Post*Inside*MH & & $\begin{array}{c}-0.144^{*} \\
(0.081)\end{array}$ & $\begin{array}{l}-0.121 \\
(0.079)\end{array}$ & $\begin{array}{c}-0.147 * \\
(0.084)\end{array}$ & $\begin{array}{l}-0.122 \\
(0.088)\end{array}$ & $\begin{array}{l}-0.137 \\
(0.082)\end{array}$ & $\begin{array}{l}-0.088 \\
(0.076)\end{array}$ & $\begin{array}{l}-0.117 \\
(0.074)\end{array}$ & $\begin{array}{l}-0.089 \\
(0.083)\end{array}$ \\
\hline Post*Inside*KT & & $\begin{array}{l}-0.093 \\
(0.081)\end{array}$ & $\begin{array}{l}-0.113 \\
(0.090)\end{array}$ & $\begin{array}{l}-0.108 \\
(0.082)\end{array}$ & $\begin{array}{l}-0.099 \\
(0.085)\end{array}$ & $\begin{array}{c}-0.130 * * \\
(0.053)\end{array}$ & $\begin{array}{c}-0.137 * * \\
(0.060)\end{array}$ & $\begin{array}{c}-0.141 * * * \\
(0.052)\end{array}$ & $\begin{array}{c}-0.136 * * \\
(0.059)\end{array}$ \\
\hline Post*Inside*AP & & $\begin{array}{c}0.136 \\
(0.085)\end{array}$ & $\begin{array}{c}0.129 \\
(0.091)\end{array}$ & $\begin{array}{c}0.126 \\
(0.086)\end{array}$ & $\begin{array}{c}0.125 \\
(0.092)\end{array}$ & $\begin{array}{c}0.099 \\
(0.061)\end{array}$ & $\begin{array}{c}0.092 \\
(0.063)\end{array}$ & $\begin{array}{c}0.097 \\
(0.063)\end{array}$ & $\begin{array}{c}0.092 \\
(0.062)\end{array}$ \\
\hline Post*Inside*Drought*KT & & & $\begin{array}{c}0.079 \\
(0.110)\end{array}$ & & $\begin{array}{l}-0.054 \\
(0.125)\end{array}$ & & $\begin{array}{c}0.029 \\
(0.135)\end{array}$ & & $\begin{array}{l}-0.031 \\
(0.117)\end{array}$ \\
\hline Post*Inside*Drought*AP & & & $\begin{array}{c}0.035 \\
(0.128)\end{array}$ & & $\begin{array}{c}0.007 \\
(0.125)\end{array}$ & & $\begin{array}{c}0.030 \\
(0.081)\end{array}$ & & $\begin{array}{c}0.029 \\
(0.076)\end{array}$ \\
\hline Rainfall Deviation & & $\begin{array}{c}0.089 \\
(0.053)\end{array}$ & $\begin{array}{c}0.087 \\
(0.053)\end{array}$ & $\begin{array}{l}0.098^{*} \\
(0.054)\end{array}$ & $\begin{array}{l}0.097 * \\
(0.054)\end{array}$ & $\begin{array}{c}0.001 \\
(0.049)\end{array}$ & $\begin{array}{c}-0.0008 \\
(0.049)\end{array}$ & $\begin{array}{c}0.014 \\
(0.049)\end{array}$ & $\begin{array}{c}0.012 \\
(0.050)\end{array}$ \\
\hline \multicolumn{10}{|l|}{ Overall effect during drought } \\
\hline & $M H$ & & $\begin{array}{c}-0.186^{*} \\
(0.098)\end{array}$ & & $\begin{array}{c}-0.275 * * \\
(0.119)\end{array}$ & & $\begin{array}{c}-0.230 * * \\
(0.110)\end{array}$ & & $\begin{array}{c}-0.264 * * * \\
(0.089)\end{array}$ \\
\hline & $K T$ & & $\begin{array}{l}-0.033 \\
(0.099)\end{array}$ & & $\begin{array}{c}-0.152 \\
(0.134)\end{array}$ & & $\begin{array}{l}-0.108 \\
(0.118)\end{array}$ & & $\begin{array}{l}-0.167 \\
(0.102)\end{array}$ \\
\hline & $A P$ & & $\begin{array}{c}0.163 \\
(0.124)\end{array}$ & & $\begin{array}{c}0.132 \\
(0.122)\end{array}$ & & $\begin{array}{c}0.122 \\
(0.086)\end{array}$ & & $\begin{array}{c}0.122 \\
(0.092)\end{array}$ \\
\hline
\end{tabular}

Notes: Standard errors are clustered at the district level and reported in parentheses below the estimated coefficient. ***,**,* denote significance at 1\%,5\% and 10\% respectively. Columns (3), (4), (7) and (8) drop the drought observations falling in the lowest 5 percent of rainfall deviation. All regressions also control for year and district fixed effects, and district-specific time trends. 